\title{
THE APPLICATION OF ESTOPPEL IN INTERNATIONAL LAW AND EXPERIENCES FOR VIETNAM
}

TRAN THANG LONG

Faculty of Legal Languages, Hochiminh city University of Law

Email: ttlong@hcmulaw.edu.vn

\section{Abstract}

In international relation, estoppel is a principle whereby a state is not able to say or act against what it said or did before. The theory of estoppel was originated in the past from the English law system, which was later incorporated into international law. Its main purpose is to prevent a State from benefiting from its inconsistent attitudes, and thus, causing damage to another State. Therefore, estoppel must meet the main conditions. First, the expression of the said State leads to the assumption of the estoppel must be clear and non-ambiguous. Second, this expression must be expressed voluntarily, unconditionally and must be well authorized. Third, there must be a goodwill trust from another State into the expression of a State giving that expression, resulting in damage to the State with this trust or to the benefit of the expressive side. The paper examines the principle of estoppel in international law and the practice of applying this principle in cases tried at the International Court of Justice. On that basis, the paper discusses explaining the factors that constitute an estoppel situation for Vietnam in order to reject the China's wrong interpretation of the 1958 Diplomatic Note of the late Prime Minister Pham Van Dong.

Keywords: estoppel, international law, diplomatic note, Pham Van Dong, Vietnam

Tntil now, whenever the issue of sovereignty disputes over the Paracel (Hoang Sa) and Spratly (Truong Sa) archipelagos is mentioned, the Chinese government often cites many kinds of historical evidence and diverse legal bases to counter the argument of Vietnam's indisputable sovereignty related to these two entities. In particular, the most focused arguments are on the letter of the late Prime Minister Pham Van Dong in 1958 which was sent to the General Secretary of the State Council of China Zhou Enlai (hereinafter referred as to Diplomatic Note 1958).

China has reiterated the existence of the Note of 1958 in the Chinese Notes sent to the UN Secretary-General. In particular, two Notes i.e. A/68/907 and A/68/956 were submitted to the United Nations in 2014 by the Chinese government during the course of the deployment of HD981 Oil Rig. Especially, the Chinese Note A/68/907 was also attached with an appendix with the full text of the Note of 1958. The inclusion 
of the Chinese Note A/68/907 in the United Nations demonstrates the importance and value of evidence that China places in the Diplomatic Note 1958. The Note A/68/907 also stated that "prior to 1974, no Vietnamese Government had ever challenged the sovereignty of China over the Xisha Islands. Viet Nam had officially recognized the Xisha Islands as part of China's territory since ancient times. But now the Vietnamese Government is going back on its word by making territorial claims over China's Xisha Islands. That is a gross violation of the principles of international law, including the principle of estoppel, and the basic norms governing international relations".

Earlier, on November 17, 2000, the Ministry of Foreign Affairs of China issued a newsletter entitled "The International Recognition of China's Sovereignty on the Spratly Islands" which stated: “ ... b) The People's Newspaper of Vietnam did report in great detail in the issue published on September 6, 1958 regarding the Statement of September 4, 1958 of the Chinese Government that the territorial width of the People's Republic of China was 12 nautical miles and this applied to all Chinese territories, including all islands in the South China Sea". On September 14 of the same year, the Vietnam's Prime Minister Pham Van Dong in a Note sent to the Prime Minister Zhou Enlai sincerely declared that Vietnam would "recognize and support the Statement of the People's Republic of China in the issue of territorial waters".

Also, according to Xinhua Newspaper dated on June 14, 2011 citing the Daily Liberation Army Newspaper stated that the Chinese government objected to any effort to internationalize the South China Sea issue. In this article there was a paragraph: "In an official statement in 1958, the Chinese government clearly stated the islands in the South China Sea as part of China's sovereignty territory, and after that, Vietnamese Prime Minister Pham Van Dong also expressed his support to this declaration". ${ }^{1}$

In contrast to the above statements, the Vietnamese government has always asserted its unquestionable legitimacy and sovereignty over these two archipelagos. Notably, on May 23, 2014, at an international press conference organized by the Ministry of Foreign Affairs in Hanoi right after the China's deployment of the HD981 Oil Rig in Vietnam's sea waters, it was again reaffirmed that China misrepresented the letter of the late Prime Minister Pham Van Dong on September 14, 1958 to China. The 1958 Note of the late Prime Minister Pham Van Dong did not mention the territorial and sovereignty issues of the two archipelagos, so it did not raise any legal issues about these two archipelagos.

See www.fmprc.gov.cn and http://linews.xinhuanet.com/english2010/indepth/2011-06/14/c_ 13929394.htm, cited in Nguyen Ba Dien (2011), 'Regarding the letter of the late Prime Minister Pham Van Dong, 14 September 1958 and the issue of sovereignty over the two islands Paracels and Spratlys of Vietnam', Journal of Sciences, Vietnam National University, no. 27, p. 240. 


\section{The concept of estoppel}

Estoppel is regarded as one of the "most powerful and flexible instruments to be found in any system of court jurisprudence". 2 The concept of estoppel in international law originated from the legal traditions, both in Anglo - American common law and European civil law systems, which the analogous concept is "preclusion" or "forclusion". Although being derived from English law, the term "estoppel" comes from the French word estouppail. The principle underlying estoppel is often expressed in the Latin maxim allegans contraria non audiendus est, which is interpreted as "one should not benefit from his or her own inconsistency". "Estoppel doctrine is said to stem from fundamental notions of justice and fairness.

These notions have been referred to in many cases tried by international tribunals as estoppel, preclusion, or equivalent terms indiscriminately, ${ }^{5}$ but the International Court of Justice (ICJ) has not been consistent in the use of terminology. However, as an international customary doctrine, it has been developed throughout the years and the use of such concept is not the same as the understanding of this in common law and civil law systems. ${ }^{6}$

According to the Black's Law Dictionary, "estoppel" is defined as (1) A bar that prevents one from asserting a claim or right that contradicts what one has said or done before or what has been legally established as true: (2) A bar that prevents the relitigation of issues; (3) An affirmative defense alleging good-faith reliance on a misleading representation and an injury or detrimental change in position resulting from that reliance. ${ }^{7}$ According to the Collins Dictionary (UK), "estoppel" is a rule of evidence whereby a person is precluded from denying the truth of a statement of facts he or she has previously asserted. ${ }^{8}$

In international law, estoppel is regarded as "a legal technique whereby states deemed to have consented to a state of affairs cannot afterwards alter their position". ${ }^{9}$ Estoppel thus obliges a State "to be consistent in its attitude to

\footnotetext{
$2 \quad$ Alexander Ovchar (2009), 'Estoppel in the Jurisprudence of the ICJ A principle promoting stability threatens to undermine it', Bond Law Review, vol. 21, issue 1, Article 5, p. 1.

Rubin (1977), 'The International Legal Effects of Unilateral Declarations', 71 American Journal of International Law, 1, 16, pp. 19-20, cited in Megan L. Wagner (1986), 'Jurisdiction by Estoppel in the International Court of Justice', California Law Review, vol. 74(5), Article 6, p. 1778.

Alexander Ovchar (2009), above n 3, page 3.

Ibid.

See Megan L. Wagner (1986), 'Jurisdiction by Estoppel in the International Court of Justice', California Law Review, vol. 74(5), Article 6, p. 1778; MacGibbon (1958), 'Estoppel in International Law', 7 International and Comparative Law Quarterly, pp. 468, 477.

Bryan A. Garner (2009), Black's Law Dictionary, West ed., p. 629.

The Collins Dictionary (2003), 'estoppel', retrieved from https://www.collinsdictionary.com/ dictionary/english/estoppel [accessed 05 March 2019].

Malcolm N Shaw (2003), International Law, Cambridge, $5^{\text {th }}$ edition, p. 439; D W Bowett (1957), 'Estoppel before International Tribunals and its Relation to Acquiescence', 33 British Yearbook of International Law, p. 176; I. Sinclair (1996), Estoppel and Acquiescence' in Fifty Years of the International Court of Justice, Cambridge, eds. A. V. Lowe and M. Fitzmaurice, p. 104.
} 
a given factual or legal situation". ${ }^{10}$ According to Oppenheim, estoppel contents two aspects. First, a State that has taken a particular position may be under an obligation to act consistently with it on another occasion. Second, when a State has acted to its detriment in relying on a formal declaration by another State, the latter may be estopped from denying its responsibility for any adverse consequences. ${ }^{11}$ Such a demand has the potential to encourage "finality, stability and predictability" in international relations. ${ }^{12}$

Estoppel is currently considered an important general principle of law and has been applied by the International Court of Justice (ICJ) in many cases ${ }^{13}$ which the Court handles such disputes as the border or related territory disputes. It often involves statements made by authorized representatives of the disputing States or relates to specific or implied behavior of relevant states... From the international law perspective, its main purpose is to prevent a State from benefiting from its inconsistent attitudes, and thus causing damage to another State.$^{14}$ Regarding border and territorial disputes, any acceptance by one party will be evidence against any subsequent contrary acts so that it would help to preclude an entity from performing inconsistent actions to cause harm other disputing parties. When one party makes a statement or expresses its consent upon which the other party has taken subsequent actions, so the party who made the said statements or conducts would not change or reject them. This meant to be proof of acknowledging the recognition or approving the act of a claimant's over a particular territory, leading to the inability of the party to reject that fact. This principle proves that international law requires goodwill and sincerity to go hand in hand with a caution to the inconsistent attitudes at different times of states in international relations. ${ }^{15}$

In its judgment in the Military and paramilitary activities in and against Nicaragua case (Nicaragua and the US), the International Court of Justice (ICJ) stated that "estoppel may be inferred from the conduct, declarations and the like made by a State which not only clearly and consistently evinced acceptance by that State of a particular régime, but also had caused another State or States, in reliance on such conduct, detrimentally to change position or suffer some prejudice. ${ }^{16}$

\footnotetext{
$10 \quad$ Iain MacGibbon (1958), 'Estoppel in International Law', 7 International and Comparative Law Quarterly, pp. 458, 468.

11 Robert Jennings and Arthur Watts (1992), Oppenheim's International Law, London, 9th ed, pp. 1188-93.

12 Territorial Dispute (Libyan Arab Jamahiriya v. Chad) (Merits) [1994] ICJ Rep 6, 78 (Separate Opinion of Judge Ajibola).

Alexander Ovchar (2009), above n 3, p. 1.

Giao duc Vietnam (2014), 'Dr. Tran Cong Truc clearly explains the principle of "Always the same" on the South China Sea', retrieved from https://giaoduc.net.vn/Xa-hoi/TS-Tran-Cong-Truc-noiro-nguyen-tac-truoc-sau-nhu-mot-ve-Bien-Dong-post152381.gd [accessed 11 April 2019].

Megan L Wagner (1986), above n 7, pp. 1777-1778.

Military and Paramilitary Activities in and against Nicaragua (Nicaragua v. the United States of America), Judgment of 26 November 1984, retrieved from https://www.icj-cij.org/files/ case-related/70/070-19841126-JUD-01-00-EN.pdf [accessed 05/5/2019].
} 
The case of Temple of Preah Vihear between Cambodia and Thailand has always been cited as a typical example for the application of estoppel in practice. The case was about a border dispute between Cambodia and Thailand. The frontier between the two states was the subject of a treaty concluded in 1904 between Thailand and France (at this time acting as the sovereign over French Indochina which Cambodia was a part of it). The treaty set up a delimitation commission and a surveillance of the borderline was duly conducted. There was, however, an ambiguous as to the siting of the Preah Vihear temple area. Thailand called for a map and the French authorities supplied them a map which placed the area within Cambodia. The Thai government accepted the map and even ordered further copies. ${ }^{17}$ A number of subsequent incidents took place, including a short visit by a Thai Prince to the temple area and was welcomed by an official reception with the French flag clearly flying there. The Court then was convinced that Thailand had implicitly accepted French sovereignty over the disputed area. It could be meant that Thailand was estopped by its conduct from claiming that it challenged the frontier in the temple area. Therefore, the Court concluded that Thailand could not oppose Cambodia's sovereignty over the temple as the following acts of the Thai government showed that they had accepted in fact the location and legal status of the temple as belonging to the French.

The Legal Status of Eastern Greenland case was another good example of estoppel. The case concerned a dispute between Denmark and Norway over sovereignty in Eastern Greenland. After a series of negotiations with some concessions from Denmark and careful consideration, the Norwegian Foreign Minister had made the "Ihlen Declaration". The Permanent Court of International Justice (PCIJ) reasoned that the Norwegian side had accepted international treaties signed with Denmark which included Danish claims of sovereignty over the entire East Greenland territory. The Court cited the Ihlen Declaration, which expressed the point of recognizing the entire Eastern Greenland to belong to Denmark. The court also argued that the statement was clear and consistent with previous Norwegian claims, and constituted an estoppel. Therefore, the Court rejected Norwegian arguments against Danish sovereignty over East Greenland territory. ${ }^{18}$

According to international practice on this issue, the expression of States giving rise to an estoppel must be a representation ${ }^{19}$ which can be in the form of unilateral statements or unilateral commitments. In addition, an estoppel

ICJ Reports (1962), pp. 6, 23, 33.

Legal Status of Eastern Greenland case (Denmark v. Norway), Judgment, retrieved from http://www. worldcourts.com/pcij/eng/decisions/1933.04.05_greenland.htm [accessed 09 May 2019].

19 Temple of Preah Vihear, 62 (Separate Opinion of Judge Fitzmaurice); Elettronica Sicula SpA (the United States of America v. Italy) [1989] ICJ Rep 15, 44. 
can be created from the fact that a State has shown its acknowledgment of another States acts or facts.

Specifically, estoppel can be formed from the following cases:

- From a unilateral statement that is legally binding

The Legal Status of Eastern Greenland case is among the first cases leading to discussions on the principle of estoppel in international law. In this case, unilateral statements were considered by the PCIJ to be binding when they were given in a wider context of negotiations between the States in question. In addition, the circumstances of this case also meet the requirements of estoppel which are clear, voluntary and trusted by the involved parties.

In Nuclear Tests case, Australia and New Zealand brought their claims to the ICJ demanding the cessation of atmospheric nuclear tests which carried out by France in the South Pacific. While the case was pending, the French government announced that it had completed its series of tests and said that it did not plan to conduct more tests. The ICJ has emphasized that a unilateral declaration can create binding legal obligations for a State making such statement only when it is expressed clearly and specifically. ${ }^{20}$ This perception was also completely confirmed by the ICJ in the Armed Activities on the Territory of the Congo case. The Court's judgment in Nuclear Tests also emphasized that "When States make statements by which their freedom of action is to be limited, a restrictive interpretation is called for". ${ }^{21}$

The ICJ decisions support the view that a unilateral act of States giving rise to an estoppel can be in one of the two ways: (i) by making a unilateral promise; or (ii) by making a unilateral statement of fact. Either of them may give rise to an estoppel. ${ }^{22}$ The ICJ has limited binding unilateral declarations to those that were intended to bind, ${ }^{23}$ but it did not distinguish between statements of fact and promises, either of which could be made with the requisite intent. For example, a State might make a declaration in which it declared that another State had a valid claim and fully intended to stand by that declaration as in the case of Eastern Greenland; or such State might make a promise to recognize the other party's claim and intend fully to be bound by such promise.

The first question is whether the form of a unilateral statement is an important factor in the formation of an estoppel? It is generally accepted that the form of a unilateral statement will not affect their validity or legal validity. The ICJ mentioned the unimportant formality of a unilateral statement in the Preah Vihear Temple case related to unilateral behavior of the party involved.

20 Nuclear Tests (Australia and France; New Zealand and France), ICJ. Reports 1974, p. 267, para 43, p. 269, para 51, and p. 472, para 46, p. 474, para 53.

$21 \quad$ Nuclear Tests, para 47, p. 473.

$22 \quad$ Megan L. Wagner (1986), above n 7, p. 1781.

$23 \quad$ Nuclear Tests, pp. 253, 267. 
Also in the Nuclear Tests, the ICJ emphasized that, for the matter of form, it can be seen that this is not an area where international law has set out specific and strict rules. Thus, a statement which made verbally or in writing does not make a significant difference for statements made in specific circumstances can create commitments in national law. As the statement is not necessarily required to be in writing, the issue of form is not decisive.

The second question is what should be the most decisive factor in the creation of an estoppel? In Nuclear Tests case, although the term "estoppel" was not used, the ICJ still bound France with its unilateral statement that atmospheric nuclear tests would end soon. The ICJ contended that the French claim was an expression of binding and thus fully valid. The Court also stressed the importance of binding intent that declaration made unilaterally by the States, according to which, the Court said that although not all unilateral statements were binding on States, the intention derived from those claims would have legal validity. Thus, the Court affirmed that, just as the very rule of pacta sunt servanda in the law of treaties is based on good faith, so is the binding character of an international obligation assumed by unilateral declaration. At the same time, it said that "unilateral declarations of a state make this state later have a legal obligation to enforce actions which are consistent with this statement". ${ }^{24}$ The ICJ's judgment also expressed the view that unilateral commitments can also create an estoppel. Although the difference between statements and commitments is not really clear, it can be seen that for such behaviors, it is important that they show a clear intention to be binding.

In the case Eastern Greenland between Norway and Denmark, the ICJ cited the Foreign Minister's Declaration, on behalf of the Norwegian Government on July 22, 1919, in which it stated clearly that "I told the Danish Minister today that the Norwegian Government would not make any difficulty in the settlement of this question [Greenland]". The ICJ reasoned that although the Ministry of Foreign Affairs had no intention of transferring and recognizing Danish sovereignty over Greenland, the Danish government was still able to rely on the commitment that Norway would not prevent Danish counterpart to deal with issues related to Eastern Greenland. Since then, the Court concluded that such a commitment of the Foreign Minister implicitly bound Norway.

In summary, a unilateral statement may lead to the creation of an obligation for such State and thus, may lead to the formation of an estoppel of international legal validity. However, such a statement will only give rise to an estoppel if it is expressed clearly and specifically. In explaining the content of such obligations, the text of the statement should be considered firstly and

$24 \quad$ Nuclear Tests, p. 268. 
serves as the foremost factors, along with consideration of the context and circumstances that the statement is given.

- No objection (lack of protest) or a silence

An estoppel can also arise from silence or inactivity (no objection). The Fisheries Case (the United Kingdom and Norway) was the first case that an estoppel arising from silence. ${ }^{25}$ The United Kingdom objected to the Norwegian system of delimitation of its coastline along the North Sea based on the argument that such system of delimitation effectively extended the Norwegian territorial sea into the high seas, which should be left open to use by all nations. However, the Court noted that the Norwegian system of delimitation was consistently applied by Norwegian authorities for a period of more than sixty years. The Court also held that, the United Kingdom should have protested against it earlier, but it did not conduct anything to contest such system. Therefore, the Court held Norway could enforce the system against the United Kingdom and the United Kingdom was now estopped from claiming this question. ${ }^{26}$

The most obvious application of estoppel was the case of the Temple of Preah Vihear between Cambodia and Thailand. In 1904, the French government in Indochina and Thailand (at that time was called Siam) went to sign an agreement whereby the French experts would map the border area. Under this agreement, the French explorers drew 11 maps in this area. One of them showed the Dangrek Mountains and placed the location of Preah Vihear temple on the side of the Cambodian border. ${ }^{27}$ The Court argued that Thailand had no objection to this map and that it led to the Thai side being obliged to comply with the created border line. This is explained by the need to ensure consistency in international relations and the specificity of mapping national borders that are to ensure their stability and final.

The question is that, whether a mere fact of silence gives rise to an estoppel? One of the approaches is that, silence and lack of protest "are so fundamental that they decide by themselves alone the matter in the dispute" and thus this constitutes "a presumption juris et de jure in virtue of which a State is held to have abandoned its right" 28 to oppose an adverse claim by another State. A juris et de jure assumption is one that denotes "conclusive presumptions of law which cannot be rebutted by evidence". ${ }^{29}$ Therefore, the consideration of other evidence which might give rise to a different inference is not necessary, hence, silence is conclusive in establishing estoppel. However, as many opposite views have

See Alexander Ovchar, above n 3, p. 12.

Fisheries Case (United Kingdom v Norway) [1951] ICJ Rep 116.

Temple of Preah Vihear, pp. 21-22.

Temple of Preah Vihear (Separate Opinion of Judge Alfaro)

Mark Shain (1944), "Presumptions under the Common and the Civil Law", 18 Southern

California Law Review, pp. 91, 97 cited in Alexander Ovchar (2009), above n 3, p. 12. 
been discussed, silence must be viewed in the context of the circumstances in which it was maintained; the presumption of consent derived from silence may be rebutted by a clear indication of the contrary intention. Silence is thus considered as having evidentiary value only. ${ }^{30}$ The author agrees with this approach, such silence does not itself constitute an estoppel unless the other factors have been investigated.

- Acquiescence

According to many scholars, an estoppel may also arise out of a State's acquiescence to the declaration of another State or to existing circumstances. ${ }^{31}$ As a commentator observes, "The few uriters who have discussed the question have had no doubt that acquiescence was... apt to found an estoppel... provided that the circumstances were such that acquiescence could be equated with recognition or consent ...${ }^{\prime 32}$ If the requirements of estoppel are met, the silence binds the acquiescing State. ${ }^{33}$

It is important that such acquiescence can be equated with recognition or consent. Just like in the case of unilateral statements, acquiescence may not always lead to the creation of an estoppel. The court can also rely on the fact surrounding the State acquiescence to explain the basis of its action or statement. However, considering the issue of acquiescence in the creation of an estoppel can lead to a debate whether it satisfies the first factor of estoppel or not, that is, the expression must be clear and unambiguous due to the acquiescence in nature does not imply an official statement.

The ICJ clarified this question in Elettronica Sicula S.p.A. case (ELSI). It argued, an estoppel could in certain circumstances arise from a silence when something ought to have been said, there are obvious difficulties in constructing an estoppel from a mere failure to mention a matter at a particular point in somewhat desultory diplomatic exchanges. ${ }^{34}$ In the of Fisheries case, the Court argued that although the United Kingdom did not have a specific statement, its silence for more than 60 years was, in fact, its acknowledgment of Norway's straight baseline. ${ }^{35}$ Similar to the Eastern Greenland case, the United Kingdom was excluded from raising a right because it was determined

30 Temple of Preah Vihear (Dissenting Opinion of Judge Spender).

31 See Fitzmaurice (1955), 'The Law and Procedure of the International Court of Justice, 1951-4: Points of Substantive Law (pt. 2)', 32 British Year Book of International Law 20, 59 ("[A] failure to protest, where a protest is called for, must have a detrimental effect on the position of the party concerned ...."). See generally Stein (1985), 'The Approach of the Different Drummer: The Principle of the Persistent Objector in International Law', 26 Harvard International Law Journal, p. 457.

32 MacGibbon (1958), 'Estoppel in International Law', 7 International and Comparative Law Quarterly, 1958, p. 501.

Megan L Wagner (1986), above n 7.

ICJ Reports, 1989, pp. 15, 54.

Fisheries Case (England and Norway), Judgment, retrieved from https://www.icj-cij.org/files/ case-related/5/005-19511218-JUD-01-00-EN.pdf [accessed 09 May 2019]. 
to be inconsistent with the United Kingdom previous position on the basis of estoppel. In addition, the Court has assumed that the estoppel principle applies when the longer the period a State keeping silent is, more bases to assert its consent to the fact are. Judgments of the ICJ such as the Gulf of Maine, Military and paramilitary activities in and against Nicaragua and the Temple of Preah Vihear... also express the view of the Court that the statements or acts must be delivered continuously and enduringly.

\section{Factors giving rise to an estoppel and the application of estoppel factors in the practice of international law}

In international law, the constitution of an estoppel requires simultaneous satisfaction of all three components: first, the expression of the relevant State leading to the assumption of an estoppel must be clear and non-ambiguous; second, this expression must be expressed voluntarily, unconditionally and must be authorized: and third, there must be goodwill reliance from another State on the expression of a State giving that expression, resulting in damage to the State with this reliance or to the benefit of the State making the expression. ${ }^{36}$ These required factors have been reaffirmed in many cases tried by the ICJ. ${ }^{37}$

\subsection{The statement giving rise to an estoppel must be clear and unambiguous}

The first factor is that the statement giving rise to an estoppel must be clear and unambiguous. ${ }^{38}$ This means that an expression of the State through a statement or act must be conducted in a concrete and transparent manner. In this case, the rules for interpreting international treaties should be applied to avoid misinterpretation of the party's intentions.

The first requirement was mentioned in a series of cases by the ICJ. In the Serbian Loans case, the Court stressed that a declaration must be "clear and unequivocal" to give rise to an estoppel. ${ }^{39}$ In the North Sea Continental Shelf case, the Court contended that the Federal Republic of Germany would be estopped only if it "clearly and consistently evinced acceptance" 40 of a Convention it did not ratify. Thus, the mere fact of taking part in the drafting of the Convention and acting in accordance with it was not enough to satisfy this criterion - only " a very definite, very consistent course of

\footnotetext{
$36 \quad$ See Megan Wagner (1986), above n 6, p. 1777; Bowett (1957), 'Estoppel Before International Tribunals and Its Relation to Acquiescence', 33 British Yearbook of International Law, pp. 176, 176; Robert Jennings and Arthur Watts (eds) (1992), Oppenheim's International Law, $9^{\text {th }}$ ed, p. 527.

For examples, North Sea Continental Shelf, Temple of Preah Vihear, Territorial Dispute. Ibid, cited in Megan L. Wagner (1986), above n 6, p. 1779.

Payment of Various Serbian Loans Issued in France (France v Serb-Croat-Slovene) [1929] PCIJ (ser A) No 20, 38.

40 Anthony D'Amato (1969), 'Consent, Estoppel, and Reasonableness: Three Challenges to Universal International Law', 10 Virginia Journal of International Law 1, 25.
} 
conduct" 41 on the part of the Federal Republic of Germany could have given rise to an estoppel in the circumstances. ${ }^{42}$

In the Land, Island and Maritime Frontier Dispute case, ${ }^{43}$ the ICJ considered the fact that El Salvador and Honduras made their expressions of "views as to the existence or nature of Nicaraguan interests". However, the Court contended that this could not give rise to an estoppel because such expressions were not clear and consistent declarations, thus, they were only ambiguous statements of opinion. In the Military and paramilitary activities in and against Nicaragua case, the ICJ observed that an "estoppel may be inferred from the conduct, declarations and the like made by a State which... clearly and consistently evinced acceptance" 44 of a particular state of affairs. Similarly, as the ICJ observed in the Landand Maritime Boundary between Cameroon and Nigeria case, an estoppel would only arise if by its acts or declarations, Cameroon had consistently made it fully clear that it had agreed to settle the boundary dispute submitted to the Court by bilateral avenues alone. ${ }^{45}$

The question is when does a statement expressing intents of the giving State constitute a legally binding obligation? The answer can be based on the rules of interpretation of international treaties stipulated in paragraph 1 of Article 31 of the Vienna Convention 1969, in which the content of the statement will be considered the first basis because they clearly reflect the intent of the party making the statement. In addition, The ICJ in the Frontier Dispute case claimed that in order to consider the intent of the party making the unilateral declaration, it is necessary to consider all the circumstances in which the acts appear. This is similar to paragraph 2 of Article 31 of the Vienna Convention 1969.

\subsection{This expression must be expressed voluntarily and unconditionally and must be authorized ${ }^{46}$}

* Voluntarily and unconditionally

The statement must be voluntary, unconditional, and it must be authorized. It means that a representation must be both authorized and unconditional. This factor is decisive. A representation which is clear and consistent may not constitute an estoppel if this factor is not satisfied. ${ }^{47}$

Ibid, p. 26.

Alexander Ovchar (2009), above n 3, p. 6.

El Salvador v Honduras (Application For Permission To Intervene) [1990] ICJ Rep 92.

Nicaragua $v$ United States of America, (Jurisdiction) [1984] ICJ Rep 392, 415.

Cameroon v Nigeria (Jurisdiction) [1998] ICJ Rep 275, 303.

See Antoine Martin (1979), 'L'Estoppel en droit international public Précédé d'un apercu de la théorie de l'estoppel en droit anglais', Revue Générale de Droit International Publie, vol. 32, p. 274 cited in Tu Dang Minh Thu (2007), 'Sovereignty over Paracel and Spratly Islands: Analyzing the Viewpoints of Vietnam and China', Thoi Dai Moi, Journal of Research and Discussion no. 11 - July 2007, retrieved from http://www.tapchithoidai.org/ ThoiDai11/200711_TuDangMinhThu.htm\#_ednref74 [accessed 03 May 2019]. Alexander Ovchar (2009), above n 3, p. 3. 
* Authorization

Regarding the authorization, the ICJ has been consistent in addressing this issue in its precedents. It has repeatedly been held that (i) a representation is authorized only if it is made by an organ competent to bind the State; and (ii) a representation is deemed unconditional, unless it is made in the course of negotiations or is subject to express conditions.

The Legal Status of Eastern Greenland case was the first to deal with the question of proper authority. The ICJ Court held that "a reply of this nature, given by the Minister for Foreign Affairs on behalf of his Government in response to a request by the diplomatic representative of a foreign Power in regard to a question falling within his province, is binding upon the state to which the Minister belongs". ${ }^{48}$ In this case, the ICJ was not concerned with the question of whether the Minister had actual authority to make the representation. Instead, the Court's focus was on whether the Minister was competent to bind the State; was the Minister given the power to engage the state internationally? When the Court concluded that it was, it observed that the representation was authorized.

The debate on the issue of "authorisation" was also in the Nottebohm case. ${ }^{49}$ In this case, the ICJ accepted that there was a clear and consistent representation. However, the Court contended that the representation was not authorized because a consulate is not an organ which is competent to bind a State. Thus it could not give responsibility to bind the State internationally on such affairs as the representation of the Consul-General of Guatemala was not authorised, it did not give rise to an estoppel. ${ }^{50}$ In the Gulf of Maine case, ${ }^{51}$ it was held by the ICJ that although a clear and consistent representation was present, a "mid-level government official" - in this case, there was the Assistant Director for Lands and Minerals of the United States Bureau of Land Management - 'had no authority to define international boundaries or take a position on behalf of his Government on foreign claims in this field". The Court thus concluded that the Assistant Director was not competent to bind the State and therefore his representation, although it was clear and consistent, did not give rise to an estoppel.

In accordance with the principles of international law, statements or actions need to be carried out on a completely voluntary basis, without coercion or bribery and it is important that they must be made by a person or a representative being fully authorized to act on behalf of the State and this must be in compliance with the national law provisions on this matter. A unilateral declaration binds the State legally and internationally only if it is done

Legal Status of Eastern Greenland, 71.

Nottebohm Case (Liechtenstein v. Guatemala) (Second Phase) [1955] ICJ Report 4.

Nottebohm Case, Ibid, page. 17-18.

Delimitation of the Maritime Boundary in the Gulf of Maine Area (Canada v United States of America) [1984] ICJ Reports 246. 
by an authorized representative. This issue has been clarified in the previous settlement practice of disputes of the Permanent Court of International Justice (PCIJ) of the League of Nations and later the International Court of Justice (ICJ) of the United Nations.

At its judgment in Military Activities in the Congo territory, the ICJ Court referred to the customary rules of international treaty law and later defined in Article 7 of the Vienna Convention 1969 on international treaty law. It is "... Heads of State, Heads of Government and Ministers for Foreign Affairs, for the purpose of performing all acts relating to the conclusion of a treaty". This issue was expressed in some cases of the PCIJ such as the Legal status of Eastern Greenland (Denmark and Norway) and of the ICJ, such as Nuclear Tests (Australia and France), the Application of the Convention on the Prevention and Punishment of Genocide (Bosnia and Herzegovina and Yugoslavia), the Arrest Warrant on April 11, 2000 (Democratic Republic of Congo and Belgium). International practice shows that unilateral declarations that constitute a legal obligation for a giving state are often given by heads of government, or foreign ministers, and are rarely given by the head of State.

\subsection{There must be good faith reliance upon the representation of one party by the other party either to the detriment of the relying party or to the advantage of the party making the representation ${ }^{52}$}

* The requirement of a reliance

In the case Temple of Preah Vihear ${ }^{53}$ despite the issue raised by Judge Alfaro that international estoppel might not require reliance, Fitzmaurice, the other Judge argued that "the party invoking the rule must have "relied upon" the statements or conduct of the other party, either to its own detriment or to the other's advantage". ${ }^{54}$ In the Military and paramilitary activities in and against Nicaragua case, the reliance requirement was reaffirmed by the ICJ that "estoppel may be inferred from the conduct, declarations and the like made by a State which... [has] caused another State or States, in reliance on such conduct, detrimentally to change position or suffer some prejudice". ${ }^{5}$

Thus, the State that claims estoppel needs to prove that it relies on the statements or activities of the other State in which it has activities, or is inactive, resulting in damage or disadvantage. In addition, the State that claims estoppel may also prove that because relying on the declaration of the other State, it had some acts or did not act while the other State benefited from the statement. The requirement for reliance is closely related to the goodwill between States in international relation. Therefore, any change of a State policy can lead to a response from the relevant State, as well as leading

Bowett (1957), above $n$ 24, cited in Megan L. Wagner (1986), above n 7, p. 1780.

Case concerning the Temple of Preah Vihear (Cambodia v. Thailand), 1962 ICJ 6.

Ibid.

Ibid, p. 392. 
to a decrease in accountability in relations between States. But, the State which claims damage by such change needs to show that they based on this reliance and changed their views, positions and behaviors.

In the Military and paramilitary activities in and against Nicaragua case, the ICJ reaffirmed the requirement for reliance to meet the requirement of estoppel principle, whereby estoppel can be derived from conduct, behavior statements and similar actions made by a State that make a State or other States rely on those conducts to change their position adversely or suffer from adverse consequences. ${ }^{56}$ In its judgment in the Continental Shelf case, the ICJ ruled that estoppel does not apply to the Federal Republic of Germany, although the said State made statements on the past to recognize the contents of the 1958 Geneva Convention on the continental shelf just because Denmark and the Netherlands did not suffer from damage by relying on those statements.

\section{The interpretation of factors of the estoppel in the case related to Paracel and Spratly archipelagos}

\subsection{Historical background}

In the course of the dispute between Vietnam and China over sovereignty over Paracel and Spratly archipelagos, the Chinese government has always affirmed that Vietnam has recognized China's sovereignty since the ancient times. As earlier mentioned, this point has been proved by the Chinese side by the Note of the late Prime Minister Pham Van Dong in 1958 to the General Director of the Chinese State Council Zhou Enlai (Official Letter 1958). This issue continues to be mentioned by the Chinese side in its White Paper of 1980 and most recently two Official Notes A/68/907 and A/68/956 issued in 2014 as mentioned earlier. In particular, the Note A/68/907 also attached in its appendix the full text of this Note.

In addition, evidence provided by Chinese government focuses on the point that Vietnam has acknowledged its sovereignty over the Paracel and Spratly archipelagos through the subsequent actions of the Democratic Republic of Vietnam (DRV) Government. With this argument, the Chinese side assumes that they have given rise an estoppel and therefore, Vietnam must not take actions against its prior acknowledgment of by the DRV Government.

The statement of the Government of the PRC regarding the territorial sea on September 4, 1958 consists of 5 points. In particular, point 1 of the original Chinese text translated into English reads as follows: The breadth of the territorial sea of the People's Republic of China shall be 12 nautical miles. This provision applies to all territories of the People's Republic of

$56 \quad$ Concerning Military and Paramilitary Activities in and Against Nicaragua (Nicaragua v the U.S.), 1984 ICJ, p. 415. 
China, including the Chinese mainland and its coastal islands, as well as Taiwan (separated from the mainland and its coastal islands by the high sea) and its surrounding islands, the Penghu Islands and the Dongsha Islands, the Xisha Islands, the Zhongsha Islands, the Nansha Islands, and all other islands belonging to China.

On September 6, 1958, Chinese Declaration on the territorial sea was publicized on the first page of the Chinese People's Newspaper. On September 14, the late Vietnam's Prime Minister Pham Van Dong issued a Diplomatic Note addressed to the Prime Minister Zhou Enlai, expressing Vietnam's respect for China's Declaration. The note was publicized on September 22 in Vietnamese People's newspaper. ${ }^{57}$ The contents of this document are read as follow:

"We would like to inform you that the Government of the Democratic Republic of Vietnam has noted and supports the September 4, 1958 Declaration by the People's Republic of China, regarding the territorial waters of China.

The Government of the Democratic Republic of Vietnam respects this decision and will direct the proper government agencies to absolutely respect the 12 mile nautical territory of China in all dealings with the People's Republic of China on the sea. We would like to send you our sincere regards".

\subsection{The contextual background and purpose of this Diplomatic Note 1958}

In order to comprehend the 1958 Diplomatic Note of the late Prime Minister Pham Van Dong, it is necessary to trace back to the historical background to understand the situation at that time.

3.2.1. The circumstances leading to the Declaration of the Government of the People's Republic of China on the territorial sea on September 4, 1958

After the Chinese mainland was liberated in 1949, in addition to the control of Taiwan island, the Kuomintang's government still kept two islands adjacent to China, Kinmen and Matsu Islands. In May 1950, as soon as the Korean War broke out, the US President Harry S. Truman ordered the $7^{\text {th }}$ Fleet to enter the Taiwan Strait with the aim to guard the island, despite China's intense condemnation. Then, on August 11, 1954, Chinese Prime Minister Zhou Enlai announced that he would "liberate" Taiwan. ${ }^{58}$

To express the determination to liberate Taiwan, on September 3, 1954, Chinese Liberation Army set fire to two coastal islands Kinmen and

$57 \quad$ Vu Thanh Ca and Le Minh Phuong, 'The 1958 Diplomatic Note of Prime Minister Pham Van Dong and Vietnam's sovereignty over the Hoang Sa and Truong Sa Archipelagos', retrieved from http://lyluanchinhtri.vn/home/en/index.php/figure-and-events/item/379the-1958-diplomatic-note-of-prime-minister-pham-van-dong-and-vietnam $\% \mathrm{E} 2 \% 80 \% 99$ ssovereignty-over-the-hoang-sa-and-truong-sa-archipelagos.html [accessed 23 April 2019]. The Wilson Center (1955), '1955 Main Speech by Premier Zhou Enlai, Head of the Delegation of the People's Republic of China, Distributed at the Plenary Session of the Asian-African Conference', retrieved from https://digitalarchive.wilsoncenter.org/document/121623. pdf?v $=\mathrm{e} 1 \mathrm{~cd} 06384 \mathrm{e} 2 \mathrm{e} 67 \mathrm{bdff1} 1 \mathrm{f} 809 \mathrm{ead} 78849$ [accessed 09 May 2019]. 
Matsu, creating the first Taiwan Strait crisis. In the tug-of-war, in August 1958, China suddenly increased its firing on Kimmen Island, leading to the second Taiwan Strait crisis. From this event, the US continued to command the $7^{\text {th }}$ Fleet to protect the logistics line from Taiwan to Kinmen and Matsu. Before the threat of territorial division, on September 4, 1958, Chinese Prime Minister Zhou Enlai issued a declaration setting a 12 nautical mile territorial sea breadth from China's mainland, including Taiwan.

In this context, the need to claim China's 12-nautical-mile territorial sea is reasonable and the need for allies' support is understandable.

3.2.2. The context of introduction of the 1958 UN Conventions on the Law of the Sea

Firstly, on April 29, 1958, the United Nations adopted four Conventions: the Convention on Territorial Waters and Contiguous Territorial Waters; the Convention on the High Sea; the Convention on Fishing and Conservation of Biological Resources in the ocean and the Convention on Continental shelf. The United Nations also issued a deadline for United Nations member States to sign this convention on territorial waters, which was due to October 31, 1958. China was not currently a member of the United Nations. In response to that situation, China made its statement on September 4, 1958 to affirm its demands on territorial waters and surrounding areas. Such statement was necessary to express Chinese views on territorial claims.

Secondly, until the early 20th century, according to State practice as well as customary law, a State's territorial waters were only up to 3 nautical miles from its baseline. Nevertheless, some States started demanding for wider width of their territorial waters to expand their sovereign territory and to seek for more privileges in the sea. Between the late 1940s and early 1950s, some States, in fact, extended their territorial waters from 3 to 12 nautical miles. This issue was not finally addressed at the United Nations Convention on the Law of the Sea held in Geneva from February 24 to April 27, 1958. For example, the United Kingdom and several States insisted on keeping the 3 nautical mile limit while some others, especially socialist States and developing states, backed for the extension of 12 nautical miles. As no agreement was reached, the regulation on the breadth of territorial waters was left open.

Thirdly, in the outset of 1950s, there was a pressure on the People's Republic of China (PRC) related to the breadth of its territorial waters. A series of armed activities raised by both the United States and China after the outbreak of the Korean War, such as the bombardments against the Kinmen and Matsu Islands and the dispatch of two US naval vessels to the Taiwan Strait aimed to protect the logistic route from Taiwan to the islands within 3 nautical miles from the coast of Kinmen Island. The PRC deemed this action a violation of its sovereignty, while the US responded it was lawful 
because these vessels operated outside the territorial waters of China. In this context, the demand for a 12 nautical miles breath of territorial waters was necessary in response to the escalating threats from the US and to invalidate the US naval activities in this region.

\subsubsection{The specific relationship between Vietnam and China at this period}

Firstly, it must be seen that the relationship between the two countries in this period was very special. At this time, the DRV and PRC were keeping "close brother" relations. Between the two countries, there have been remarkable practical help. For example, in 1949, the Viet Minh occupied the Chinese territory of Truc Son from other forces and later returned it to the Chinese People's Liberation Army. In 1957, China occupied Bach Long Vi island of Vietnam from some other forces, and also returned it to Vietnam. ${ }^{59}$

Since 1956, the DRV in the North sought for the supports of the international community, focusing on reunification the nation. The international proletarian movement at this period had much affection and support for the North of Vietnam. China was one of the socialist governments that actively supported the DRV.

Also at this stage, Vietnam had to concentrate all forces for the highest goal against the aggressive US war, to protect national independence. In this context, China gave Vietnam a great support and invaluable help. In that spirit and being rooted in the urgent demands mentioned above, the statement of the leaders of Vietnam was necessary because it directly served the struggle to protect independence and freedom for Vietnam itself. It had nothing to do with historical and legal bases of Vietnam's sovereignty over Paracel and Spratly archipelagos. ${ }^{60}$

Secondly, at the time of the Diplomatic Note, the world situation was so complicated. The world was divided into two blocks: capitalist and socialist, which were fierce oppositions by the cold war. The United States intervened in the South of Vietnam for its global strategic interests. Meanwhile, the Soviet Union pursued the goal of balancing the powers with the United States, and China aimed to become a world power. For Vietnam, supports from the Soviet Union and China were also served for the demand to oppose the opposition. In such context, the United States' aggression or compromise towards the Soviet Union and China could always place a huge impact on Vietnam.

$59 \quad$ VNExpress (2014), 'What are the contents of the Note of 1958', retrieved from https://vnexpress. net/thoi-su/cong-thu-1958-co-noi-dung-nhu-the-nao-2994952.html\#ctr=related_news_ click [accessed 03 May 2019].

60

As spoken by Mr. Nguyen Manh Cam, former Vice Prime Minister and Minister of Foreign Affairs in a meeting in Ha Noi on 2/12/1992; Vietnamnet (2014), 'Who benefited from the Note of 1958', retrieved from https://vietnamnet.vn/vn/tuanvietnam/ai-huong-loi-tu-congthu-1958-177354.html [accessed 04 May 2019]. 
Thirdly, as earlier mentioned, as the US government stepped up its military presence in the region, China was forced to be in the risk for the first time to involve in a direct military conflict with the US Navy. This situation put DRV Government into a situation which having no choice to express its support and solidarity with the Chinese government. The Diplomatic Note of the late Prime Minister Pham Van Dong made in a state of urgency, that is, the war with the US began to escalate, the US 7 Fleet being operated in the Taiwan Strait and directly threatened China.

In this context, the 1958 Diplomatic Note of the late Prime Minister Pham Van Dong was suitable to the specific circumstances and relationships between the DRV and the People's Republic of China at that time. The Note was only a good gesture about friendship and support for China while the US brought the 7th fleet to the Taiwan Strait. ${ }^{61}$ Therefore, it is necessary to stand in that spirit and the context of the years 1950 - 1960 of the last century to comprehend the Note of the late Prime Minister Pham Van Dong. This Note is a reflection of the reality in the respectable period of Vietnam - China friendship. ${ }^{62}$ The Note was only intended to support China against the US siege policy in the Taiwanese Strait, threatening Chinese national security at that time and more importantly, it did not contain any of Vietnam's abandonment of sovereignty over the Paracel and Spratly archipelagos.

\subsection{The nature of and the interpretation of texts of the Diplomatic Note 1958}

3.3.1. The 1958 Diplomatic Note should be understood as a diplomatic letter (diplomatic note)

This issue should be viewed from the following perspectives:

First, the Note should be understood as a unilateral diplomatic document expressing the Democratic Republic of Vietnam's (DRV) solidarity with the People's Republic of China. Diplomatic Notes are also a common form of socialist countries at the time which was used to display ideological unity with each other, expressing the spirit of brotherhood in the international proletarian movement. ${ }^{63}$

Second, considering both contents and context of the Note, it should also be interpreted as a unilateral promise, or a statement of intent of a state to do something (declaration of intention). In this particular situation, it was to support China's 12 nautical miles territorial claim and consisted of two main contents: (i) a promise to respect China's government decision in setting up Chinese territorial waters, and (ii) a promise to order Vietnam's authorities to respect the width of Chinese territorial sea.

\footnotetext{
$\overline{61}$ As spoken by Mr. Luu Van Loi, former Chief of Office, Assistant to Minister of Foreign Affairs, Head of Border Department belonging to the Council of Ministers (1978-1989).

62 See Nguyen Ba Dien (2011), above n 1, p. 242.

63 VNExpress (2014), "The Note of 1958 had no legal effect", retrieved from https://vnexpress.net/ thoi-su/cong-thu-1958-khong-co-gia-tri-phap-ly-2995323.html [accessed 03 May 2019].
} 
Third, even in China's Declaration in September 4, 1958, it also showed an ambiguity in referring to China's genuine sovereignty over the Paracel and Spratly Islands, because the point (4) of this Declaration only mentioned recapturing Taiwan and Penghu which were still under occupation of the United States, it did not mention the recapture of the Xisha (Paracel) and Nansha (Spratly).

\subsubsection{The "intent" of the Note should be carefully interpreted}

The 1958 Note, as analyzed, is essentially a unilateral statement. The question here is whether such a unilateral statement is possible to create a legal binding obligation for the State giving the statement, and then whether it gives rise to an estoppel or not?

Obviously, a mere promise is very difficult to legally bind the state that made this promise, unless it clearly shows the intent of the given State. The ICJ practice presents another condition to bind such a promise: that is the actual will of a promised State. It means that whether the State is really willing to be bound by its promise or not. The ICJ judgments shows that, in order to determine the "intent" factor, the Court needs to consider all the facts surrounding that statement, checking if it had been stated, in what context and under what conditions (circumstances). In the Nuclear Tests case between Australia/New Zealand and France, France declared it would stop the atomic experiment. The court ruled that France was bound by the promise because France really wanted to be bound by that promise. Without this "intent" factor, the Court will conclude that the State making the statement does not really want to be bound when giving that statement and thus, such a statement is not binding. This perception was reaffirmed in other cases tried by the ICJ, such as Armed Activities on the Territory of the Congo. ${ }^{64}$

Therefore, it will be a blatant distortion of history, having no legal basis when considering only the texts in a diplomatic document, then concluding the abandon of Vietnam's sovereignty and acknowledgement of China's sovereignty over the Paracel and Spratly archipelagos.

\subsection{Analysing three core factors to constitute an estoppel}

3.4.1. The expression of the relevant State leading to the assumption of an estoppel must be clear and non-ambiguous

When considering the contents of the Note 1958, it is clear that the message conveyed by the Government of the DRV is "to acknowledge and endorse the Declaration dated on September 4, 1958 of the Government of the People's Republic of China". This sentence means that the Vietnamese side acknowledged China's wish to extend its waters through its unilateral declaration, and therefore it would agree with this aspiration. And the

Armed Activities on the Territory of the Congo (the Democratic Republic of the Congo $\mathrm{v}$ Rwanda), Jurisdiction and Admissibility, paras 50 and 52. 
next paragraph might imply that in the good relationship between the two countries at that period, the Vietnamese side would respect the determination of China for a 12 nautical milesterritorial water. In particular, there was no word or dedication that could be assumed to be a declaration to renounce Vietnam's sovereignty over the Paracel and Spratly archipelagos.

From the whole Note and its words, it could be seen that the true intent of the late Prime Minister Pham Van Dong lied completely in the issue of the territorial width of 12 nautical miles that China had just declared. They did not carry any other meaning as analyzed. Therefore, the statement did not explicitly express the recognition of China's sovereignty over the Paracel and Spratly archipelagos. In particular, the Note reads: "The Government of the $D R V$ respects this decision and will direct the proper government agencies to absolutely respect the 12 mile nautical territory of China in all dealings with the People's Republic of China on the sea. We would like to send you our sincere regards".

In summary, an interpretation of the content of the Note in the direction that it was the declaration to recognize China's sovereignty was completely inaccurate, showing a deliberate distortion of the words, contrary to basic rules of interpretation of international treaties under the law of treaties, in which the terms of the treaty must be interpreted in their context and must be considered in a whole (Article 31(2) and (3) of Vienna Convention 1969 of the Law of Treaties). Therefore, an estoppel cannot be established by the 1958 Note.

\subsubsection{The expression must be voluntary, unconditional and authoritative}

The problem here is whether the Note meets the authority criteria. This should be determined by two issues: (i) according to the provisions of the present-time Constitution, was a letter from the Prime Minister fully authorized by law? and (ii) would such a statement be legally valid under international law?

Firstly, whether the 1958 Diplomatic Note was made under the name of the Prime Minister being in accordance with the provisions of the 1946 Constitution?

Some Vietnamese scholars ${ }^{65}$ take the viewpoint of whether or not this Note was made in accordance with assigned power or not? These views are based on the argument under which the Prime Minister is a governmental agency in the DRV, which, according to the present time (i.e. the Constitution of 1946), was that of the Government, and the Government was the highest administrative body under the National Assembly. ${ }^{66}$ The head of the Government is the President of the State. The President of the State, along with the National Assembly are empowered to "act on behalf of the

\footnotetext{
65 See, for example, Nguyen Ba Dien (2011), above $n 1$.

$66 \quad$ Article 43 and 52 of Constitution of Democratic Republic of Vietnam (1946).
} 
State" as well as to "address all issues for the whole nation" ${ }^{67}$ including national territory. At the same time, the 1946 Constitution also stipulated that for "Decisions affecting national destiny may be submitted to the people for decision by means of a referendum, with the agreement of two-thirds of the total Membership of the National Assembly" ${ }^{68}$ Hence, it can be concluded that according to such provisions, the Note of 1958 was made by a person lacking of necessary power to deal with issues of the national territory, so it could not constitute an expression that leads to estoppel.

For example, according to Nguyen Ba Dien, the Prime Minister of the DRV did not have authority to act on behalf of the State to decide on issues related to the territory of the country with foreign countries. Because according to Article 32 of the Constitution of the DRV dated on November 9, 1946, problems related to the fate of the State will be decided by referendum on condition that $2 / 3$ of the total the member (National Assembly delegates) agrees, and the way of the decision will be decided by law". 69

However, such an argument is not persuasive and lack of legal basis from the perspective of international law. Under contemporary rules of international law which are specified in the field of treaty law, a State may not invoke the fact that its consent to be bound by a treaty has been expressed in violation of a provision of its internal law regarding competence to conclude treaties as invalidating its consent unless that violation was manifest and concerned a rule of its internal law of fundamental importance.

Secondly, whether the Note of 1958 could be entitled to deal with the Paracel and Spratly archipelagoes?

It is worth to note that the Geneva Accord 1954 is the most important and unique legal document in the $20^{\text {th }}$ century asserting that Paracel and Spratly archipelagos belong to Vietnam. As the arrangement of the Geneva Accord in 1954, Vietnam was temporarily divided into two zones. The territory from the $17^{\text {th }}$ parallel to the South, including the Paracels and Spratly archipelagos was set under the control of the State of Vietnam which was succeeded by the Republic of Vietnam (ROV). ${ }^{70}$ The Geneva Accord also set the control of the DRV the territory of Vietnam to the north of the $17^{\text {th }}$ Parallel. By adhering to the Accord, there was an indirect recognition of

\footnotetext{
$67 \quad$ Article 22, 23 and 49 of Constitution of Democratic Republic of Vietnam (1946).

68 Article 21 and 32 of Constitution of Democratic Republic of Vietnam (1946).

$69 \quad$ Nguyen Ba Dien (2011), above n 1, pp. 240-245.

$70 \quad$ Geneva Accord 1954, Article 4: "The provisional military demarcation line between the two final regrouping zones is extended into the territorial waters by a line perpendicular to the general line of the coast. All coastal islands north of this boundary shall be evacuated by the armed forces of the French Union, and all islands south of it shall be evacuated by the forces of the People's Army of Viet-Nam". See https://peacemaker.un.org/sites/peacemaker.un.org/files/KH-LA-VN_540720_ GenevaAgreements.pdf, accessed on 01/5/2019.
} 
the administration of the SOV over the territory of Vietnam to the south of the 17th Parallel, including the two archipelagos, while waiting for an election for national reunification. As the scheduled general election in July of 1956 could never be held for many reasons, there was in fact the co-existence of two separated entities in Vietnam. ${ }^{71}$ After that, these two governments coexisted as two political entities correspondingly administered the Northern and Southern parts of Vietnam. Notably, both of them declared on the territorial integrity of Vietnam and asserted their wish to unify Vietnam. From 1954 to 1976, the SOV and then the ROV, and finally the Socialist Republic of Vietnam have peacefully, continuously and effectively governed the two archipelagos as prescribed in the international law. ${ }^{72}$

According to Monique Chemillier Gendreau, under these conditions, certain statements or positions of the DRV government had no effect on sovereignty. She argued that the DRV was not entitled to manage these islands and thus, one cannot give up what one does not have power. The DRV government was dependent on its allies (i.e. China) in the context of an unequal war against the United States. ${ }^{73}$ The viewpoint was repeated by the Vietnamese officers making his conclusion in a press conference held in 2014, in which "the logic is that you cannot give to others anything when you have not yet acquired it". This view is acceptable.

In addition, the ROV was a political entity and could be internationally recognized as a special entity in international relations. Therefore, the ROV was entitled to manage and enforce sovereignty over these two archipelagos as the result of the Geneva Accord 1954. The 1933 Montevideo Convention on the Rights and Duties of States explicitly concluded "the political existence of a State is independent of recognition by other States" 74 and hence, the relevance of the State of Vietnam and later the ROV, as well as their administration over the two archipelagos from 1954 to 1975 could not be affected by any recognition or non-recognition from other states.

First, the ROV acted as the administrator over the assigned territory from the $17^{\text {th }}$ parallel onwards and as the successor of the titles, rights and claims left by the French on the two archipelagos under the 1954 Geneva Accord. The ROV, in fact, carried out activities to the archipelagos until Vietnam was reunified in 1975.

71 James Crawford (2007), The creation of States in international law, Oxford University Press, Gendreau M. C. (1998) Sovereignty over the Truong Sa and Hoang Sa Archipelagos, Hanoi: National Political Publishing House, Vu Thanh Ca, 'Vietnam's Continued Sovereignty over the Truong Sa and Hoang Sa Archipelagos', retrieved from http://lyluanchinhtri.vn/ home/en/index.php/theory-research/item/327-the-continuation-of-vietnam $\%$ E2\%80\%99ssovereignty-over-hoang-sa-and-truong-sa-archipelagos.html [accessed 08 April 2019]..

Vu Thanh Ca, above $n 57$ [accessed 03 April 2019].

Monique C Gendreau (1998), Sovereignty over the Truong Sa and Hoang Sa Archipelagos, Hanoi: National Political Publishing House.

Montevideo Convention on the Rights and Duties of States, Article 3. 
In 1956, after the withdrawal of the French colonialists, the ROV sent troops to regain control over the western group of islands in the area of the Paracel (in April 1956) and Spratly archipelagos (in August 1956). The ROV conducted administrative activities, investigation and economic exploitation and effective protection of the two archipelagos. For the Paracel, examples of the administrative activities of the ROV government include: granting permits for exploitation of bird droppings on three islands of Quang Anh (Money Island), Huu Nhat (Robert Island) and Truong Sa in 1956, 1959, 1973; merging the Paracel Islands into Quang Nam province in July 1961; conducting naval patrol in the waters around the island, handling Chinese illegal fishing vessels to the islands.

The ROV Government subsequently issued many legal documents confirming its administration to the archipelagos, such as the Declaration No. 2289 on June 4, 1956 of the Minister of Foreign Affairs of Vietnam to assert the Paracel and Spratly belonged to Vietnam; the Decree No. 143-NV dated October 22, 1956 of the President of the ROV on the administrative territory of South Vietnam, whereby the Spratly Islands, together with Ba Ria and Vung Tau were merged into Phuoc Tuy province; the Decree No. 24/BNV of the Ministry of Home Affairs regarding the appointment of Mr. Nguyen Ba Thuan to assume the position of Administrative Correspondent at the Paracel on December 14, 1960; the Decree No. 174-NV by the President of the ROV on merging Paracel archipelago into Quang Nam province on July 13, 1961; the Official Note No. 120 dated January 21, 1974 of the President of the Senate of the ROV, Tran Van Lam sent to the Secretary-General of the United Nations on the occasion of China taking over the Paracel Islands of Vietnam... ${ }^{75}$

Second, the ROV government also made use of the forum at the $2^{\text {nd }}$ Session of the Third UN Conference on the Law of the Sea in Caracas in 1974 to reaffirm its entitlement to these two archipelagos. ${ }^{76}$ Also, a remarkable detail is that in 1974, the Provisional Revolutionary Government of the South Vietnamese Republic reiterated that "sovereignty and territorial integrity were sacred issues for each nation". Thus, the two governments affirmed

Nguyen Ba Dien (2011), above n 1, p.243.

Proclamation by the Government of the Republic of Vietnam dated 14 February, 1974 stressed:

"The Hoang Sa (Paracel) and Truong Sa (Spratly) archipelagoes are an indivisible part of the territory of the Republic of Vietnam. The Government and People of the Republic of Vietnam shall not yield to force and renounce all or part of their sovereignty over those archipelagoes.

As long as one single island of that part of the territory of the Republic of Vietnam is forcibly occupied by another country, the Government and People of the Republic will continue their struggle to recover their legitimate rights.

The illegal occupant will have to bear all responsibility for any tension arising therefrom.

On this occasion, the Government of the Republic of Vietnam also solemnly reaffirms the sovereignty of the Republic of Vietnam over the islands off the shores of Central and South Vietnam, which have been consistently accepted as a part of the territory of the Republic of Vietnam on the basis of undeniable geographic, historical and legal evidence and on account of realities". 
themselves to represent South Vietnam (being the entity given the right to govern the two archipelagos) shared a common attitude on this issue, without breaking Vietnam's sovereignty over two archipelagos.

Concerning this argument, the question is whether or not it would lead to an inaccurate understanding that after the 1954 Geneva Agreement, the division of Vietnam into two regions according to the division of the 17th parallel led to form two separate States (i.e. Democratic Republic of Vietnam (DRV) in the North and Republic of Vietnam (ROV) in the South. This will undoubtedly lead to different consequences that are not covered in this article. The core understanding of this division under the Geneva Agreement is that Vietnam was temporarily divided into two regions (rather than separated into two independent States - as some people have recently mistaken), taking the 17 th parallel as a temporary line, the DOV managed the North, while South Vietnam was taken over by the ROV, including both the Paracel and Spratly archipelagos.

The fact that there were two de facto political entities in two regions in Vietnam was understandable, derived from the reality of Vietnam's situation after the 1954 Geneva Accord and there are some similar cases, such as the case of East and West Germany before 1990. It should be noted that both entities exercised the control over each territorial division and this could not be regarded as creating two independent States. The issue here is to determine which entity had actual management authority over territorial parts under its control. In this case, these are two completely different issues and there should be no assumption or concern about whether or not there were two independent States in Vietnam before 1975.

3.4.3. The good faith reliance upon the representation of one party by the other party either to the detriment of the relying party or to the advantage ofthe party making the representation

In applying the above core factors constituting an estoppel to the statement of the DRV deprived of the Note 1958, there was a lack of conditions (2) (leading to damage to the subject with this trust) and (3) (leading to the benefit of the expressive side) mentioned above.

In 1956, 1958 and 1965, China had no attitude, or changed attitudes which based on the proclamation of the DRV. China could not prove that it did suffer any damage based on those statements. The DRV also did not benefit from its statements. ${ }^{77}$ The statements of the late Prime Minister Pham Van Dong were entirely due to the Vietnam - China friendship with no intention of referring to the sovereignty, the key factor that might lead

\footnotetext{
$77 \quad$ Nguoi Dai bieu Nhan dan (2014), 'The Note of 1958 viewed from international law perspective', retrieved from http://daibieunhandan.vn/default.aspx?tabid=76\&NewsId=318273 [accessed 04 May 2019].
} 
to the Chinese side's confidence in Vietnam's position over the Paracel and Spratly archipelagos.

The 1965 statement later made by the Government of the DRV, was in the same effect. The driving force of that statement was the urgency and danger in Vietnam. These were political statements, not legal ones. Therefore, the Chinese government must understand that, in the context of appearing Vietnamese statement, it cannot be the basis for the "reliance" in asserting China's sovereignty or the abandonment of Vietnam's sovereignty over the two archipelagos.

Both governments in South Vietnam took strong action against China's seizure against the Paracel. Right after the naval battle on January 19, 1974, on January 19, 1974, the ROV Ministry of Foreign Affairs issued a statement against China's invasion. Similarly, the Provisional Revolutionary Government of the Republic of South Vietnam also opposed China's actions, asserting Vietnam's sovereignty over the Paracel archipelago. As soon as the collapse of the Government of the ROV collapsed on April 30, 1975, the army of the Provisional Revolutionary Government of the Republic of South Vietnam took over the Spratly Islands and handed it over to the Government of the DRV at the reunification in 1976.

The above events show that after the ROV Government ended its existence, the next Government after 1975 did not have any sovereignty concessions or agreements relating to the Paracel and Spratly Islands.

In summary, all of the above explanations show that the Diplomatic Note of the late Prime Minister Pham Van Dong on September 14, 1958 was merely a diplomatic declaration, it did not have the effect of recognizing sovereignty related to the two archipelagos. The Note lack many necessary factors to be able to constitute an estoppel. The "reliance" factor (that is, the State based on the statement of the other suffers from damage), and the "intent" factor (i.e., the State that made the promise was intended to be bound by that promise) serve as the key issues.

\section{Conclusion}

From 1954 until now, the Congress and the Government of the ROV, the National Liberalization Front and then the Provisional Revolutionary Government of the Republic of South Vietnam and today, the National Assembly of the Socialist Republic of Vietnam have never declared or issued any resolution to renounce Vietnam's sovereignty as well as to recognize China's sovereignty over the Paracel and Spratly archipelagos.

The 1958 Diplomatic Note was simply a unilateral diplomatic document supporting China's declaration of its territorial water width of 12 nautical miles and was given on the ties between the two countries in 
the socialist block. The Note was made in urgent circumstances, in which the war threatened by the US and the conflicts in the Taiwan Strait were escalating. In addition, as being analyzed, the Paracel and Spratly archipelagos were not mentioned specifically in the Note, making it invalid as a piece of evidence for Vietnam's recognition of China's sovereignty over the islands as the Chinese side has often mistakenly cited.

Vietnam's firm point of view is that China has misquoted the 1958 Diplomatic Note of the late Prime Minister Pham Van Dong. Vietnam's arguments are based on the core conditions of the estoppel principle, which requires the simultaneous satisfaction of all three components: first, the expression of the relevant State leads to the assumption of the estoppels must be clear and not ambiguous; second, this expression must be expressed voluntarily and unconditionally and must be authorized; third, there must be good faith from another State into the expression of a State that makes the expression, resulting in damage to the State having such reliance, or leading to the enjoyment benefit from the State making such expression. The analysis of this article has shown that the above factors are not satisfied. Finally, the 1958 Diplomatic Note did not mention the territorial and sovereignty issues over the two archipelagos Paracel and Spratly, so it causes no legal binding for these two archipelagos.

\section{Reference}

[1] D W Bowett (1957), 'Estoppel before International Tribunals and its Relation to Acquiescence'. 33 British Yearbook of International Law

[2] James Crawford (2007), The creation of States in international law, Oxford University Press

[3] Anthony D'Amato (1969), 'Consent, Estoppel, and Reasonableness: Three Challenges to Universal International Law', 10 Virginia Journal of International Law 1, 25

[4] Nguyen Ba Dien (2011), 'Regarding the letter of the late Prime Minister Pham Van Dong, 14 September 1958 and the issue of sovereignty over the two islands Paracels and Spratlys of Vietnam', Journal of Sciences, Vietnam National University, no. 27

[5] Fitzmaurice (1955), 'The Law and Procedure of the International Court of Justice, 1951-4: Points of Substantive Law (pt. 2)', 32 British Year Book of International Law 20, 59

[6] Bryan A. Garner (2009), Black's Law Dictionary, West ed.

[7] Monique C Gendreau (1998), Sovereignty over the Truong Sa and Hoang Sa Archipelagos, Hanoi: National Political Publishing House

[8] Robert Jennings and Arthur Watts (1992), Oppenheim's International Law, London, 9th ed

[9] MacGibbon (1958), 'Estoppel in International Law', 7 International and Comparative Law Quarterly

[10] Alexander Ovchar (2009), 'Estoppel in the Jurisprudence of the ICJ A principle promoting stability threatens to undermine it', Bond Law Review, vol. 21, issue 1, Article 5

[11] Rubin (1977), 'The International Legal Effects of Unilateral Declarations', 71 American Journal of International Law, 1, 16

[12] Mark Shain (1944), 'Presumptions under the Common and the Civil Law', 18 Southern California Law Review

[13] Malcolm N Shaw (2003), International Law, Cambridge, $5^{\text {th }}$ edition

[14] I. Sinclair (1996), Estoppel and Acquiescence' in Fifty Years of the International Court of Justice, Cambridge, eds. A. V. Lowe and M. Fitzmaurice

[15] Megan L. Wagner (1986), 'Jurisdiction by Estoppel in the International Court of Justice', California Law Review, vol. 74(5), Article 6 